\title{
Performance of Different Dietary Lipids on Growth Indices and Survival of Striped Gourami, Colisa fasciatus (Perciformes: Osphronemidae) Fry
}

\author{
M.S. Hossen", A.H.M.M. Reza, S.F. Rakhi, Z. Hossain \\ Department of Fisheries Biology and Genetics, Bangladesh Agricultural University, Mymensingh-2202, Bangladesh \\ *Corresponding Author: shafaet.fbg@bau.edu.bd
}

Copyright (C) 2014 Horizon Research Publishing All rights reserved.

\begin{abstract}
Effects of different types of lipids enriched supplemental diets containing $1 \%$ docosahexaenoic acid (DHA), 1\% Phospholipids, 5\% Cod liver oil and 1\% Cod liver oil and live feed (Tubificid worms) on growth indices and survival of Colisa fasciatus fry were observed. The experiment was conducted in triplicates with a control for 50 days following randomized complete block design (RCBD). The water quality parameters were monitored and found to be within suitable range for freshwater aquaculture. After ending the trial period, significant variations $(P<0.05)$ were observed on the survival and specific growth rate of fry among all the treatments. These results indicate that there are significant variations among different lipids on performance of fry and DHA showed the highest performance regarding growth indices and survival (in close proximity to live feed) among all the biofunctional lipids as an ingredient of supplemental diet.
\end{abstract}

Keywords Colisa fasciatus, Spawning, Lipids, Growth, Survival, Fry Rearing

\section{Introduction}

Fish farming has been the fastest growing sector of animal food production in the world since 1970. Due to stagnating wild fisheries and a growing human population, aquaculture is expected to fill the gap in supplies of fish as food for human, as demand continues to increase [1]. For ensuring the sustainability of the aquaculture industry and nutritional view point more indigenous fish species should be brought in culture.

The striped gourami, Colisa fasciatus is a common species under the family Osphronemidae found in Asia. It is, in fact, a dual purpose fish in that it has delicious taste, thereby, meeting the nutritional requirements of peoples and it also has ornamental values for aquaria [2]. The fish is omnivore in nature therefore; it is easy to feed on live, frozen and flake feeds [2]. In the past, this species was readily available in freshwater pools, ditches, ponds, marshes, rivers as well as lakes with vegetation. The natural resources of this species are fast declining in Bangladesh due to drastic reduction of the natural feeding and breeding ground as a result of human intervention, climate change and modification of its habitats. At present $C$. fasciatus is under 'Lower Risk-near threatened' category although is not listed in the IUCN Red Data Book [3] and is now a high-priced fish [4].

Lipid represents a concentrated and cost-effective energy source in the formulated fish diet. However, lipids also have other important nutritional functions, including structural roles in cell membranes, as components in hormones, as precursors for prostaglandins and other eicosanoids, and as sources for essential fatty acids (EFAs). EFAs are unsaturated fatty acids that must be provided preformed in the diet as vertebrates cannot synthesize these EFAs [5]. In freshwater fishes, EFA requirements can usually be met by supplying the shorter-chain precursors: linolenic acid (LNA; 18:3[n-3]), linoleic acid (LA; 18:2[n-6]) or both, although better growth performance can be often achieved by supplying the "bioactive", polyunsaturated fatty acids (PUFAs) forms in the diet [6]. These fatty acids are stored in fish as energy reserves in various organs, exclusively in muscles and liver. Fatty acids composition in fish is seasonal and a great portion of these lipids are transferred to different parts of the body for using various physiological processes such as growth, migration and reproduction [7].

One important aspect of larval nutrition is providing adequate levels of lipids, proteins, carbohydrates, vitamins and minerals through the diet [6]. Especially DHA plays an important role in nutritional physiology and reflects in excellent growth and survival for the fish larvae and fry that often required in addition to carbohydrates [8]. DHA is an important component for developing nervous systems in both invertebrates and vertebrates for their normal development [9]. Moreover, DHA results in EFA enhancement providing eicosanoids which positively enhance immunocompetence in fish larvae and fry. 
Inadequate contents of this EFAs particularly in the diet give rise to several behavioral and morphological abnormalities such as poor feeding and swimming activities, reduce growth and dropping mortality, fatty livers, abnormal pigmentation, disgregation of gill epithelia, immune-deficiency and raise cortisol levels [10]. However, the incorporation of lipids in fish feed ingredients may be the solution to these problems. Information is available on the biology of $C$. fasciatus particularly, food habits, maturity, spawning and length weight relationships [11], fecundity [12], effect of feed quality on growth and gonadal maturity [13], development of air breathing organ [14], morpho-histology of the alimentary canal [15], sexual dimorphism [16] and various physiological alterations during early life stages [17] of $C$. fasciatus. However, the effects of lipids incorporation in fry diet on growth performance of $C$. fasciatus is yet quite limited. Therefore, the present study was undertaken to evaluate the effectiveness of several types of lipids on growth and survivability of $C$. fasciatus fry rearing in order to harvest healthy fish.

\section{Materials and Methods}

\subsection{Collection and Rearing of $\boldsymbol{C}$. Fasciatus Fry}

A total of 15 fry of two weeks old having similar initial size $(1.29 \pm 0.23 \mathrm{~cm} / 17.8 \pm 6.24 \mathrm{mg})$ were set in plastic bowls at the Wet Laboratory, Faculty of Fisheries, Bandgladesh Agricultural University (BAU), Mymensingh, Bangladesh. Each bowl was $31 \mathrm{~cm}$ deep having an internal diameter of 42 $\mathrm{cm}$ with an effective water holding capacity of $20 \mathrm{~L}$ and facilitated for continuous flow of water from the porous PVC pipes as inlet along with outlet facilities. Three different types of lipid enriched diets viz. 1\% DHA, 1\% phospholipids, $5 \%$ Cod liver oil, $1 \%$ Cod liver oil and a live feed (Tubificid worms) were used as treatments with a control. All the treatments were replicated three times. Therefore, a total of 16 plastic bowls were used where 15 bowls for treatments $(3 \times 5)$ and rest one was for control and the experiment was conducted following randomized complete block design (RCBD). Control diet contained the same supplemental ingredients as of treatment except the external lipid. Before starting of feeding trial the fry were acclimatized for 3 days in the bowls. The composition of experimental fry diet are shown in Table 1 and proximate analysis of the dietary ingredients (was carried out for crude protein, crude fat, carbohydrate, ash and moisture determination following the standard methods as given by Association of Official Analytical Chemists, [18]). Shelters were made with broken earthen pots locally known as "chara" in the bowls as the larvae had a tendency to cluster in the shelter. The feeds were provided thrice daily (at 07:30, 12:00 and 17:00 hours) and continued for a duration of 50 days. During the study, water temperature by using a celcius thermometer, $\mathrm{pH}$ by a portable digital $\mathrm{pH}$ meter (MICRO-TEMP, $\mathrm{pH}$ 500) and dissolved oxygen (DO) by a digital DO meter (multi $340 \mathrm{i} / \mathrm{set}$, DO-5509; Germany) were recorded as $26.5 \pm 1{ }^{\circ} \mathrm{C}, 7.5 \pm 0.2$ and $6.8 \pm 0.4 \mathrm{ppm}$, respectively.

Table 1. Ingredients of experimental diet for C. fasciatus fry

\begin{tabular}{|c|c|c|c|c|}
\hline $\begin{array}{c}\text { Specific } \\
\text { ingredients for } \\
\text { larval diet }\end{array}$ & $\begin{array}{l}\text { Inclusion } \\
\text { level (\%) }\end{array}$ & $\begin{array}{l}\text { Common } \\
\text { ingredients }\end{array}$ & $\begin{array}{l}\text { Inclusion } \\
\text { level (\%) }\end{array}$ & $\begin{array}{c}\text { Preparation } \\
\text { of } 200 \mathrm{~g} \\
\operatorname{diet}(\mathrm{g})\end{array}$ \\
\hline DHA & 1 & $\begin{array}{l}\text { Wheat } \\
\text { flour }\end{array}$ & 10 & 20 \\
\hline Phospholipids & 1 & Wheat bran & 15 & 30 \\
\hline Cod liver oil & 5 & Rice bran & 13.5 & 27 \\
\hline Cod liver oil & 1 & $\begin{array}{c}\text { Maize } \\
\text { meal }\end{array}$ & 20 & 40 \\
\hline $\begin{array}{l}\text { Live feed } \\
\text { (Tubificid } \\
\text { worm) }\end{array}$ & - & Fish meal & 40 & 80 \\
\hline $\begin{array}{l}\text { Control diet } \\
\text { without any } \\
\text { lipids }\end{array}$ & - & Vitamin-B & 0.5 & 1 \\
\hline- & - & Vitamin-E & $2.5 \mathrm{IU} / \mathrm{g}$ & $500 \mathrm{IU}$ \\
\hline
\end{tabular}

\subsection{Performance Evaluation of $\boldsymbol{C}$. Fasciatus Fry}

Periodic sampling of fry was done to assess the growth and health performances of fry every after ten days. The mean length and weight were measured from random samples of five fry after collection from each bowl. Weight (mg) was taken by digital electric balance and the length $(\mathrm{cm})$ by placing the fry on a Petridis placed on a graph paper. Further, the final mean length, weight, survival and specific growth rate (SGR) and feed conversion ratio (FCR) of fry were recorded at the time of harvesting. Sampling was done before application of food to avoid the biasness of weight due to presence of excessive food. The following parameters were considered:

$$
\text { Length gain }(\mathrm{cm})=\text { Average final length - Average initial length }
$$$$
\text { Weight gain }(\mathrm{mg})=\text { Average final weight - Average initial weight }
$$

Average final length - Average initial length

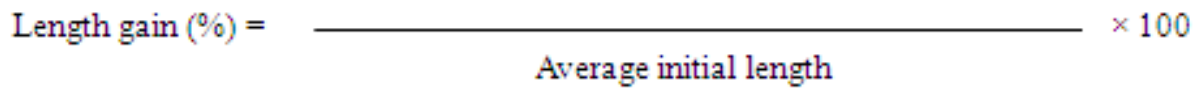




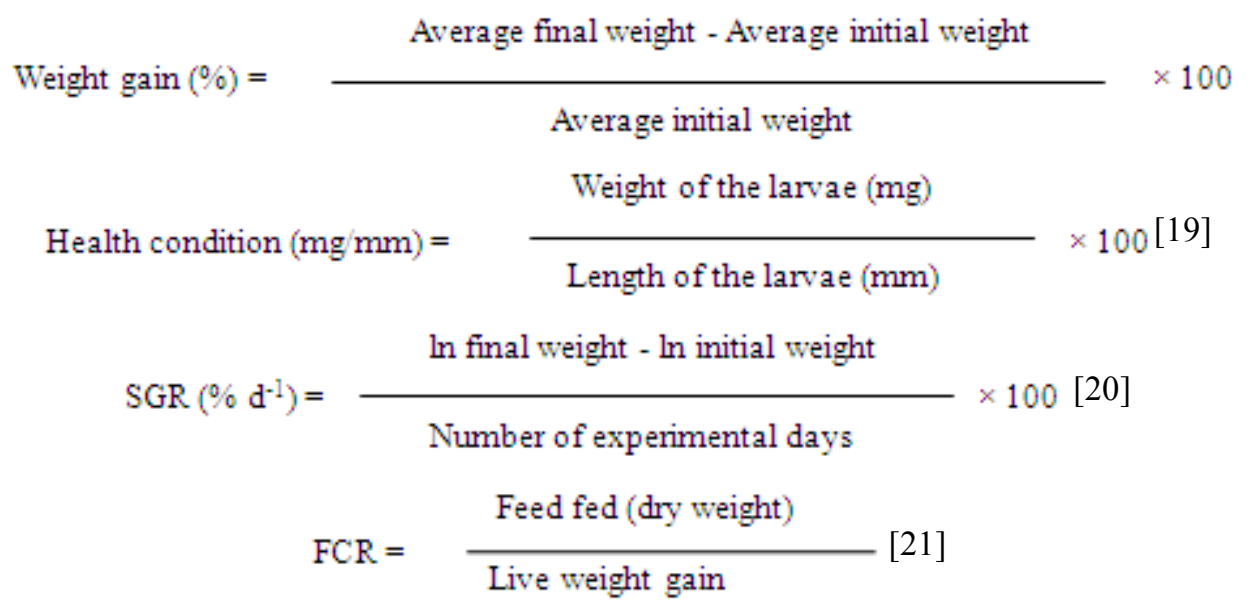

\section{Statistical Analysis}

Statistical analysis was performed using Mstat-C: 3.0 program. The evaluations of the treatments was made by one-way analysis of variance (ANOVA) and when differences were found significant, Duncan Multiple Range Test (DMRT) was conducted to determine specific differences in treatment means. Differences were considered statistically significant at $P<0.05$.

\section{Results}

\subsection{Composition Analysis of Dietary Ingredients}

Proximate composition analysis of feed was done to verify the accuracy of the formulation and the results are shown in Table 2. The total percent lipid content of dietary ingredients were $3.90,24.70,8.44,4.43$ and 5.73 for wheat flour, rice bran, fish meal, wheat bran and maize meal, respectively. The overall fatty acid content of total lipids in the dietary ingredients were not determined in this experiment due to administration of same supplemented diet other than specific lipids was provided and the main purpose of the experiment was to monitor the effects of different dietary lipids on growth performances of $C$. fasciatus fry.

Table 2. Proximate composition of different dietary ingredients (Dry matter basis)

\begin{tabular}{|cccccc|}
\hline $\begin{array}{c}\text { Feed } \\
\text { Ingredients } \\
\text { Wheat }\end{array}$ & $\begin{array}{c}\text { Protein } \\
(\%)\end{array}$ & $\begin{array}{c}\text { Lipid } \\
(\%)\end{array}$ & $\begin{array}{c}\text { Carbohydrate } \\
(\mathrm{NFE})(\%)\end{array}$ & $\begin{array}{c}\text { Ash } \\
(\%)\end{array}$ & $\begin{array}{c}\text { Moisture } \\
(\%)\end{array}$ \\
flour & 10.92 & 3.90 & 72.94 & 0.32 & 11.92 \\
Rice bran & 17.73 & 24.70 & 19.76 & 9.44 & 13.99 \\
Fish meal & 62.40 & 8.44 & 0.1 & 15.42 & 13.61 \\
$\begin{array}{c}\text { Wheat bran } \\
\text { Maize } \\
\text { meal }\end{array}$ & 14.57 & 4.43 & 55.72 & 4.93 & 10.64 \\
\hline
\end{tabular}

4.2. Effects of Different Dietary PUFAs on Growth of $C$. fasciatus Fry
After 50 days feeding trial, the final mean length were recorded as $1.89 \pm 0.19 \mathrm{~cm}, 2.27 \pm 0.45 \mathrm{~cm}, 2.11 \pm 0.39 \mathrm{~cm}$, $2.05 \pm 0.30 \mathrm{~cm}, \quad 1.97 \pm 0.17 \mathrm{~cm}$ and $2.40 \pm 0.57 \mathrm{~cm}$ for control, DHA, phospholipids, $5 \%$ cod liver oil, $1 \%$ cod liver oil and live feed respectively. The mean final weights of the fry were reached at $97.67 \pm 14.14 \mathrm{mg}, 175.20 \pm 7.56 \mathrm{mg}$, $152.33 \pm 9.58 \mathrm{mg}, 142.87 \pm 10.39 \mathrm{mg}, 135.40 \pm 15.84 \mathrm{mg}$ and $199.87 \pm 5.31 \mathrm{mg}$ for control, DHA, phospholipids, $5 \%$ Cod liver oil, $1 \%$ Cod liver oil and live feed respectively during that time. The growth indices of fry varied significantly among different dietary lipids fed to the fry (Table 3 ). The uppermost performances were observed among all the parameters studied when live feed was given to the fry and was significantly different $(P<0.05)$ from all other treatments. However, among the dietary lipids fed to the fry DHA showed the highest percent weight gain, length gain, health condition, survival rate, SGR and FCR viz. $884.27 \pm 21.86 \%, 76.61 \pm 14.58 \%, 7.71 \pm 0.91,79.67 \pm 1.49 \%$, $4.44 \pm 0.15 \%$ and $1.42 \pm 0.05$ respectively. Furthermore, percent weight gain did not differ significantly when all the other lipids except DHA such as PL, 5\% Cod liver oil, 1\% Cod liver oil were given to fry (Table 3) but percent length gain was recorded lowest in case of $1 \%$ Cod liver oil. The growth trends (weight gain and length gain) of $C$. fasciatus fry under different treatments during rearing period of 50 days are shown in Fig. 1 and Fig 2.

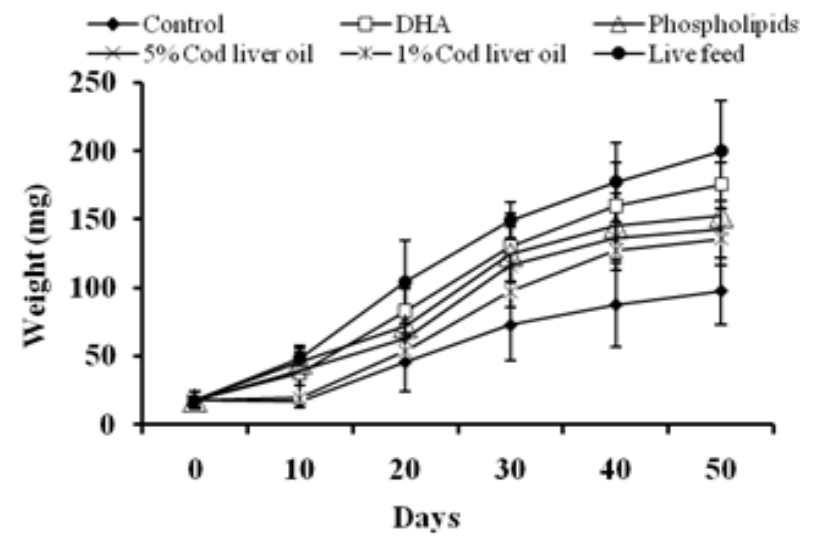

Figure 1. Weight (mg) gain of C. fasciatus fry during the 50 days experimental period. Vertical bars $= \pm \mathrm{SD}$ 


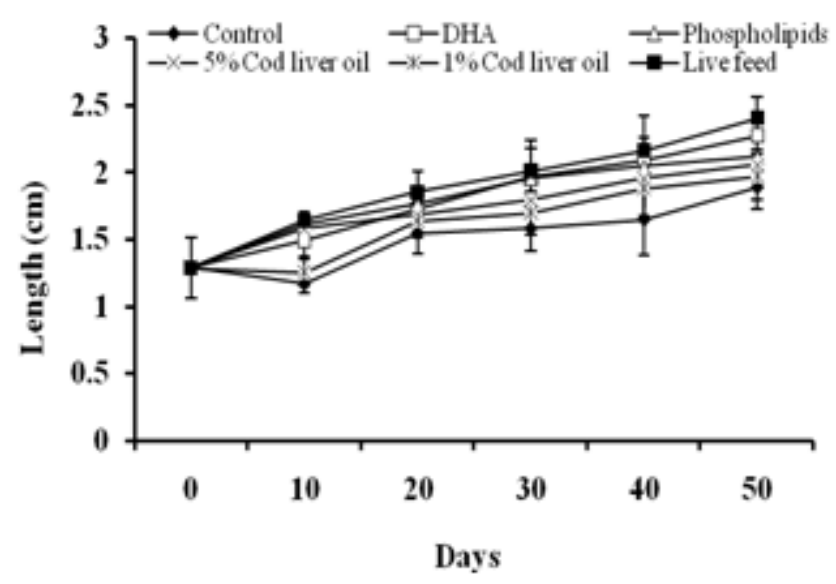

Figure 2. Length $(\mathrm{cm})$ gain of $C$. fasciatus fry during the 50 days experimental

\section{Discussion}

The lipids are considered as the physiologically active factor in many species and their incorporation into food as biofunctional compounds is an effective way to enhance growth and reproductive performances of fishes. In the present investigation different lipids were incorporated in reasonable amount into the food ingredients, so that the fry can synthesize fatty acids for their normal physiological activities according to their necessity. The overall fatty acid content of total lipids in the dietary ingredients were not determined in this experiment due to administration of same supplemented diet other than specific lipids was provided and the main purpose of the experiment was to monitor the effects of different dietary lipids on growth performances of C. fasciatus fry. From other studies, it was found that fatty acid composition of rice bran contain $32.0 \pm 0.2 \%$ of $n-6$ fatty acid and $1.6 \pm 0.0 \%$ of $n-3$ fatty acid of total fat. Wheat flour and wheat bran fat include $0.41 \%$ and $2.21 \%$ PUFAs (g) of whole grain respectively. Maize meal fatty acids include linoleic acid (18:2n-6) $5.614 \mathrm{~g} / \mathrm{kg}$, linolenic acid (18:3n-3) $0.198 \mathrm{~g} / \mathrm{kg}$, DHA (22:6n-3) $0.258 \mathrm{~g} / \mathrm{kg}$ (The New Times Company, Calorie count 2011; SELF Nutrition Data, [22]).

The results revealed that among the three types of lipids enriched diets for rearing of $\mathrm{C}$. fasciatus fry, $1 \%$ DHA showed the best performance with respect to weight gain, percent weight gain and length gain, percent length gain, health condition, survival rate, SGR along with FCR followed by the $1 \%$ PL, $5 \%$ Cod liver oil, $1 \%$ Cod liver oil. A growing body of evidence suggests the positive role of DHA on growth, survival and pigmentation of fish larvae and fry [23]. A significant effect of dietary DHA on larvae and fry growth and he also opined that DHA is especially needed for high cellular turn-over [24]. n-6 fatty acids (DHA) are recommended for reproduction as well as growth of eel [25] and black sea bass larvae is supported by [26]. The result of present study is in line with that found by [27] which showed minimum dietary levels of DHA in diets for larval gilthead seabream to be $0.8 \%$. The DHA were also found to be more efficiently utilized by the freshwater fish common carp [28] and DHA in particular, has a high biological value during larval development [25]. In gilthead seabream larvae, dietary DHA in microdiets was recognized for promoting growth and larval survival [29]. Higher growth performance of DHA could be due to it's particular structure which provides this fatty acid with many important functions in fish metabolism. DHA gets incorporated into cell membranes, regulates membrane integrity and function. Moreover, DHA as an important component of phosphoglycerides, particularly phosphatidyl ethanolamine and phosphatidyl choline, serve as an energy reservoir in larvae and fry that retained in starved or low-EFA fed fish, possibly due to the lower cell oxidation rates than other fatty acids.

The PL showed the performance next to DHA. Our result is clearly supported by the findings of [10] who stated that dietary deficiencies or imbalances in PL induce mortality and delay growth in fish larvae and fry with its notable effects on the formation of cell membranes needed for normal development. Optimizing the PL level in the diet which results in enhanced lipid deposition and increased energy availability for growth and ovarian development [30].

In the present work, we incorporated live feed as another treatment and found extraordinary growth performance in $\mathrm{C}$. fasciatus fry. This outstanding result of live feed is obvious as it is a natural and extremely nourishing food for larvae and fry of a number of fish species and having high food value (5575 cal g-1 dry weight) [31]. [32] reported the percentage crude protein, lipid, ash and moisture content of tubificid worm as $11.02 \pm 0.58,2.14 \pm 0.06,1.83 \pm 0.16$ and $18.78 \pm 0.83$ respectively. Total fatty acid content is $7.28 \mathrm{mg} / 100 \mathrm{mg}$ dry weight and n-3 (C18:3n-3 and C20:5n-3) and n-6 (C18:2n-6c and $\mathrm{C} 20: 4 \mathrm{n}-6$ ) fatty acids composed $18 \%, 22 \%$ of the total respectively. The most abundant amino acids (amino acid $\mathrm{g} / 100 \mathrm{~g}$ protein) are lysine $(6.54 \pm 0.12)$, leucine $(6.52 \pm 0.13)$ followed by arginine (5.39 \pm 0.04$)$, valine (4.92 \pm 0.09$)$, threonine (4.81 \pm 0.09$)$, phenylalanine $(4.36 \pm 0.09)$, isoleucine $(4.31 \pm 0.08)$, tyrosine $(2.74 \pm 0.07)$, histidine $(2.67 \pm 0.03)$ and methionine (1.82 \pm 0.04$)$ White sturgeon (Acipenser transmontanus) grew $40 \%$ larger on Tubifex sp. compared to inanimate pellets was the findings of [33].

On the contrary, Cod liver oil both in $5 \%$ and $1 \%$ condition had the reduction in growth performance in all parameters studied. Similar and comparable result is found in previous work with African catfish (Heterobranchus longifilis) by [34]. The depressed growth effects of Cod liver oil could be due to the presence of highest levels of linoleic acid (18:2n-6) (11.20 $\pm 0.10 \%)$ [35]. Tilapia, rockfish and carp fed diets containing linoleic acid exhibited significantly low,er weight gain and feed efficiencies (g weight gain/g dry feed) compared with fish fed diets containing no linoleic acid as reported by [36]. In addition, the levels of total n-3 PUFAs, EPA, DHA content and n-3/n-6 ratio in Cod liver oil supplemental diet may remain much higher and the use of unbalanced feeds in terms of fatty acid composition cause of higher level of lipids accumulation in liver and intestine. And when the lipid level exceeds the capacity of the hepatic cells 
to oxidize fatty acids then protein synthesis impaired resulting the synthesis and deposition of large amounts of triglycerides in vacuoles, leading to steatosis or hepatic lipidosis as well as microvesicular (foamy degeneration) and macrovesicular degeneration in the liver hindering normal growth and development of fry $(37,38,39)$. However, few other scientists reported their findings that are a bit conflicting to our present data. In particular, [40] worked with cultured brown trout (Salmo trutta) and [29] with rainbow trout (Oncorhynchus mykiss) to verify the effects of complete or partial substitution of fish oil with animal oils on the growth, survival and fatty acid composition and both of them found enhanced fry growth performance in salmonids. These discrepancies plausibly caused by the species differences, the variation of nutritional needs, morphology, feeding behaviour of different fish larvae and fry, the habitat or cultured environment and the influence of other water quality parameters, or simply due to the differences between the fish collected from sea, river, reservoir, haor and beel or the small and large fish.

In fine, it can be concluded that the DHA has a significant effects on growth and survival of $\mathrm{C}$. fascitus fry than any other lipids in the fry diets. However, further study is crucial to find out the mechanism responsible for enhanced fry growth due to DHA supplementation in fry diet.

Table 3. Growth performance (weight gain, percent weight gain, health condition, survival rate and specific growth rate) of C. fasciatus fry during 50 days

\begin{tabular}{|c|c|c|c|c|c|c|c|c|c|}
\hline Treatment & $\begin{array}{c}\text { Replicatio } \\
\mathrm{n}\end{array}$ & $\begin{array}{l}\text { Length } \\
\text { gain }(\mathrm{cm})\end{array}$ & $\begin{array}{l}\text { Length gain } \\
(\%)\end{array}$ & $\begin{array}{l}\text { Weight gain } \\
\text { (mg) }\end{array}$ & Weight gain (\%) & $\begin{array}{c}\text { Health } \\
\text { condition } \\
(\mathrm{mg} / \mathrm{mm})\end{array}$ & $\begin{array}{c}\text { Survival } \\
(\%)\end{array}$ & $\begin{array}{c}\text { SGR (\% } \\
\left.\text { day }^{-1}\right)\end{array}$ & FCR \\
\hline \multirow{4}{*}{ Control } & $\mathrm{R} 1$ & 0.57 & 44.52 & 74.20 & 416.85 & 4.95 & 49 & 3.08 & 1.90 \\
\hline & $\mathrm{R} 2$ & 0.63 & 49.18 & 81.60 & 458.43 & 5.18 & 50 & 3.10 & 1.83 \\
\hline & $\mathrm{R} 3$ & 0.59 & 46.08 & 83.80 & 470.79 & 5.40 & 48 & 2.89 & 1.82 \\
\hline & Mean & $\begin{array}{c}0.60 \pm 0.29 \\
\mathrm{f}\end{array}$ & $\underset{f}{46.62 \pm 15.62}$ & $79.87 \pm 4.55^{\mathrm{f}}$ & $448.69 \pm 21.98^{f}$ & $\underset{\mathrm{d}}{5.18 \pm 1.06}$ & $\begin{array}{c}49.00 \pm 2.97 \\
\mathrm{f}\end{array}$ & $\underset{f}{3.02 \pm 0.12}$ & $\underset{\mathrm{d}}{1.85 \pm 0.13}$ \\
\hline \multirow{4}{*}{ DHA } & R1 & 1.01 & 78.71 & 160.40 & 901.12 & 7.75 & 80 & 4.44 & 1.41 \\
\hline & $\mathrm{R} 2$ & 0.99 & 77.16 & 158.60 & 891.01 & 7.74 & 80 & 4.30 & 1.45 \\
\hline & R3 & 0.95 & 74.05 & 153.20 & 860.67 & 7.63 & 79 & 4.59 & 1.40 \\
\hline & Mean & $\begin{array}{c}0.99 \pm 0.19 \\
\text { b }\end{array}$ & $\underset{\mathrm{b}}{76.61 \pm 14.58}$ & $157.40 \pm 6.87^{\mathrm{b}}$ & $884.27 \pm 21.86^{\mathrm{b}}$ & $\begin{array}{c}7.71 \pm 0.91 \\
\mathrm{~b}\end{array}$ & $\begin{array}{c}79.67 \pm 1.49 \\
\mathrm{~b}\end{array}$ & $\begin{array}{c}4.44 \pm 0.15 \\
b\end{array}$ & $\begin{array}{c}1.42 \pm 0.05 \\
\mathrm{~b}\end{array}$ \\
\hline \multirow{4}{*}{$\begin{array}{c}\text { Phospholipid } \\
\text { s }\end{array}$} & $\mathrm{R} 1$ & 0.83 & 64.72 & 135.00 & 758.43 & 7.21 & 71 & 4.07 & 1.48 \\
\hline & $\mathrm{R} 2$ & 0.81 & 63.17 & 132.60 & 744.94 & 7.16 & 69 & 3.89 & 1.51 \\
\hline & $\mathrm{R} 3$ & 0.83 & 64.72 & 136.00 & 764.04 & 7.25 & 71 & 3.56 & 1.54 \\
\hline & Mean & $\underset{c}{0.83 \pm 0.19}$ & $\underset{c}{64.18 \pm 13.95}$ & $134.53 \pm 9.15^{\mathrm{c}}$ & $755.81 \pm 20.70^{\mathrm{c}}$ & $\underset{c}{7.21 \pm 0.73}$ & $\underset{\mathrm{c}}{70.33 \pm 1.93}$ & $\underset{c}{3.84 \pm 0.26}$ & $\underset{\mathrm{b}}{1.51 \pm 0.08}$ \\
\hline \multirow{4}{*}{$\begin{array}{l}5 \% \text { Cod liver } \\
\text { oil }\end{array}$} & R1 & 0.73 & 56.95 & 126.20 & 708.99 & 7.13 & 63 & 3.72 & 1.67 \\
\hline & $\mathrm{R} 2$ & 0.79 & 61.62 & 123.80 & 695.51 & 6.81 & 56 & 3.32 & 1.64 \\
\hline & $\mathrm{R} 3$ & 0.77 & 60.06 & 125.20 & 703.37 & 6.94 & 59 & 3.51 & 1.64 \\
\hline & Mean & $0.77 \pm 0.17$ & $\underset{\mathrm{d}}{59.52 \pm 13.70}$ & $125.07 \pm 23.33^{\mathrm{d}}$ & $702.62 \pm 19.51^{\mathrm{d}}$ & $\underset{c}{6.96 \pm 0.96}$ & $\underset{\mathrm{d}}{59.33 \pm 1.68}$ & $\begin{array}{c}3.51 \pm 0.20 \\
\mathrm{~d}\end{array}$ & $\underset{\mathrm{c}}{1.65 \pm 0.09}$ \\
\hline \multirow{4}{*}{$\begin{array}{c}1 \% \text { Cod liver } \\
\text { oil }\end{array}$} & R1 & 0.69 & 53.85 & 119.00 & 668.54 & 6.91 & 53 & 3.19 & 1.69 \\
\hline & $\mathrm{R} 2$ & 0.67 & 52.29 & 119.00 & 668.54 & 6.98 & 54 & 3.04 & 1.73 \\
\hline & R3 & 0.67 & 52.29 & 114.80 & 644.94 & 6.77 & 49 & 3.39 & 1.68 \\
\hline & Mean & $\begin{array}{c}0.68 \pm 0.16 \\
\mathrm{e}\end{array}$ & $\underset{\mathrm{e}}{52.84 \pm 13.56}$ & $117.60 \pm 15.84^{\mathrm{e}}$ & $660.67 \pm 18.50^{\mathrm{e}}$ & $\begin{array}{c}6.88 \pm 0.99 \\
\mathrm{c}\end{array}$ & $\begin{array}{c}52.00 \pm 1.97 \\
\mathrm{e}\end{array}$ & $\begin{array}{c}3.21 \pm 0.18 \\
\mathrm{e}\end{array}$ & $\underset{\mathrm{d}}{1.70 \pm 0.10}$ \\
\hline \multirow{4}{*}{ Live feed } & $\mathrm{R} 1$ & 1.15 & 89.59 & 184.60 & 1037.08 & 8.30 & 85 & 4.78 & 1.22 \\
\hline & $\mathrm{R} 2$ & 1.03 & 80.26 & 171.20 & 961.80 & 8.15 & 83 & 4.94 & 1.19 \\
\hline & R3 & 1.15 & 89.59 & 190.40 & 1069.66 & 8.53 & 88 & 4.83 & 1.22 \\
\hline & Mean & $\underset{\mathrm{a}}{1.11 \pm 0.15}$ & $\begin{array}{c}86.48 \pm 12.61 \\
a\end{array}$ & $182.07 \pm 23.55^{\mathrm{a}}$ & $1022.85 \pm 17.48^{\mathrm{a}}$ & $\begin{array}{c}8.33 \pm 0.80 \\
\mathrm{a}\end{array}$ & $\begin{array}{c}85.33 \pm 1.49 \\
\mathrm{a}\end{array}$ & $\begin{array}{c}4.85 \pm 0.28 \\
\mathrm{a}\end{array}$ & $\begin{array}{c}1.21 \pm 0.04 \\
\mathrm{a}\end{array}$ \\
\hline
\end{tabular}

Mean values in the column with different superscripts are significantly different 


\section{REFERENCES}

[1] FAO, 2008. The State of World Fisheries and Aquaculture. Fisheries and Aquaculture Department, Food and Agriculture Organization of the United Nations, Rome, Italy. P: 25.

[2] Goodwin, D., 2003. The practical aquarium fish handbook. Sterling Publ Co. p: 256.

[3] Anonymous, 2006. IUCN red list of threatened species. http://www.redlist.org.

[4] Rainboth, W.J., 1996. Fishes of the Cambodian Mekong. FAO Species Identification Field Guide for Fishery Purposes, FAO. P: 218.

[5] Bell, M.V., R.J. Henderson, and J.R. Sargent. 1986. The role of polyunsaturated fatty acids in fish. Comparative Biochemistry and Physiology 81B:193-205.

[6] Kanazawa, A., 2003. Nutrition of marine fish larvae. J. Appl. Aquac.,13: 103-43.

[7] Kandemir, S. and N. Polat, 2007. Seasonal variation of total lipid and total fatty acid in muscle and liver of rainbow trout (Oncorhynchus mykiss W., 1792) reared in Derbent Dam Lake. Turk. J. Fish. Aquat. Sci., 7: 27-31.

[8] D'Abramo, L.R., 2002. Challenges in developing successful formulated feed for culture of larval fish and crustaceans. Memorias del VI Simposium Internacional de Nutricion Acuicila, pp: 143-149.

[9] Castell, J.D, J.G. Bell, D.R. Tocher and J.R. Sargent, 1994. Effects of purified diets containing different combinations of docosahexaenoic acid on survival, growth and fatty acid composition of trout (Sophthalmus maximus L.). Aquaculture, 128: 315-333.

[10] Izquierdo, M.S., 1996. Essential fatty acids requirements of cultured marine fish larvae. Aquaculture Nutr., 4: 183-191.

[11] Mitra, K., V.R. Suresh, G.K. Vinci, N.N. Mazumdar and D.K. Biswas, 2007. Biology and Fishery of Banded Gourami, Colisa fasciata (Bloch and Schneider, 1801) in a Floodplain Wetland of Ganga River Basin. Asian Fish. Sci., 20: 409-423.

[12] Behra, S., M.I. Khan, S.K. Das, and T.S. Nagesh. 2005. On the fecundity of stripped gourami, Colisa fasciata (Bloch and Schneider). J. Inland Fish. Soc. India 37(1): 68-70.

[13] Chakrabarty D., S.K. Das, M.K. Das, and M.P. Bag. 2010. Low cost fish feed for aquarium fish: a test case using Colisa fasciata. Spanish J. Agril. Res. 2010 8(2): 312-316.

[14] Prasad, M.S., A.P. Mishra, and B.R. Singh. 1982. Development of the air breathing organ in Colisa fasciatus (B1 and Schn). Archivio italiano di anatomia e di embriologia 87: 243-261.

[15] Moitra, S.K., and A.K. Ray.1977. Morpho-histology of the alimentary canal of an Indian fresh-water perch, Colisa fasciata (Bloch) in relation to food and feeding habits. Anatomischer Anzeiger 141 (1): 37-58.

[16] Dehadrai, P.V., S.R. Banerji, N.K. Thakur, and N.K. Das. 1973. Sexual dimorphism in certain air breathing teleosts. J.
Inland Fish. Soc. India 5: 71-77.

[17] Kumari, P.,and M.S. Prasad. 1983. Changes in the water-blood diffusion barrier of secondary gill lamellae during early life of Colisa fasciatus. Zool. Anzeiger Jena. 211: 108-114.

[18] AOAC (Association of Official Analytical Chemists), 1980. Official methods of analysis of Association of Official Analytical Chemists (ed. W. Hoewitz), 13th edition Washington, D.C. p: 78.

[19] Mollah, M.F.A., M.S.A. Mamun, M.N. Sarowar, and A. Roy. 2009. Effects of stocking density on the growth and breeding performance of broodfish and larval growth and survival of shol, Channa striatus (Bloch). J. Bangladesh Agricultural University 7(2): 427-432.

[20] Brown, M.E., 1957. Experimental studies on growth. In: M.E. Brown (ed), The Physiology of Fishes. Academic Press. New York, 1: 361-400.

[21] Halver, J. E., 1972. Fish Nutrition. Academic Press Inc. New York, p: 718.

[22] SELF Nutrition Data, 2012. Web adds: nutritiondata.self.com/facts/cereal-grains-and-pasta/5742/2.

[23] Bransden, M.P., G.M. Butterfield, J. Walden, L.A. McEvoy and J.G. Bell, 2005. Tank colour and dietary arachidonic acid affects pigmentation, eicosanoid production and tissue fatty acid profile of larval Atlantic cod (Gadus morhua). Aquaculture, 250: 328-340.

[24] Le Milinaire, C., 1984. Etude du besoin en acides gras essentiels pour la larve de turbot (Psetta maxima L.) pendant la phase d'alimentation avec le rotifère Brachionus plicatilis. Université de Brest, France, p: 168.

[25] Furuita, H., K. Hori, N. Suzuki, T. Sugita and T. Yamamoto, 2007. Effects of n-3 and n-6 fatty acids in broodstock diet on reproduction and fatty acid composition of broodstock and eggs in the Japanese eel Anguilla japonica. Aquaculture, 267: 55-61.

[26] Rezek, T.C., W.O. Watanabe, M. Harel and P.J. Seaton, 2010. Effects of dietary docosahexaenoic acid (22:6n-3) and arachidonic acid (20:4n-6) on the growth, survival, stress resistance and fatty acid composition in black sea bass Centropristis striata (Linnaeus, 1758) larvae. Aquaculture Res., 41(9): 1302-1314.

[27] Izquierdo, M.S., A. Obach, L. Arantzamendi, D. Montero, L. Robaina and G. Rosenlund, 2003. Dietary lipid sources for seabream and seabass: growth performance, tissue composition and flesh quality. Aquaculture Nutr., 9: 397-407.

[28] Takeuchia, T. and T. Watanabe, 1977. Requirement of carp for essential fatty acids. Bull. Jap. Soc. Sci. Fish., 43: 541-551.

[29] Liu, K.M., F.T. Barrows, R.W. Hardy and F.M. Dong, 2004. Body composition, growth performance, and product quality of rainbow trout (Onchorhynchus mykiss) fed diets containing poultry fat, soybean/corn lecithin or menhaden oil. Aquaculture, 238: 309-328.

[30] Gonzalez-Felix, M.L., D.M. Gatlin III, A.L. Lawrence and M. Perez- Velazquez, 2002. Effect of dietary phospholipids on essential fatty acid requirements and tissue lipid 
composition of Litopenaeus vannamei juveniles. Aquaculture, 202: 151-167.

[31] Mollah, M.F.A. and M.T. Ahamed, 1989. A note on preliminary study of culture of Tubificids worms. Bangladesh J. Fish., 12(2): 91-95.

[32] Mahmut, Y., Y. Yasemen, and G.M. Ayçe. 2003. Tubifex Tubifex (Annelidae) in Besin Kompozisyonu. E.U. J. Fish. \& Aquatic Sci., 20(1-2): 103-110.

[33] Buddington, P.K. and S.J. Doroshov, 1984. Feeding trials with hatchery produced white sturgeon (Acipenser transmontanus). Aquaculture, 36: 237-243.

[34] Legendre, M., N. Kerdchuen, G. Corraze and P. Bergot, 1995. Larval rearing of African catfish, Heterobranchus longifilus (Teleostei, Clariidae): effect of dietary lipids on growth, survival and fatty acid composition of fry. Aquat. Living Resour., 8: 355-363.

[35] Kürsat Bayraktar and Abdulkadir Bayir, 2012. The effect of the replacement of fish oil with animal fats on the growth performance, survival and fatty acid profile of rainbow trout juveniles, Oncorhynchus mykiss. Turk. J. Fish. Aquat. Sci.,12: 661-666.
[36] Choi, B.D., S.J. Kang, Y.L. Ha and R. G. Ackman, 1999. Accumulation of conjugated linoleic acid (CLA) in tissues of fish fed diets containing various levels of CLA. In: Quality Attributes of Muscle Foods (Xiong, Y. L., C.T. Ho and F. Shahidi, eds.) p: 61-71. Kluwer Academic/Plenum Publishers, New York, NY.

[37] Gisbert, E., L. Villeneuve, J.L. Zambonino, P. Infante, C. Quazuguel and L. Cahu, 2005. Dietary phospholipids are more efficient than neutral lipids for long chain polyunsaturated fatty acid supply in European sea bass Dicentrarchus labrax development. Lipids, 40: 1-10.

[38] Genc, E., E. Yilmaz and I. Akyurt, 2005. Effects of dietary fish oil, soy-acid oil, and yellow grease on growth and hepatic lipidosis of hybrid tilapia fry. Isr. J. Aquac. Bamidgeh, 57(2): 90-96.

[39] Tacon, A.G.J., 1996. Lipid nutritional pathology in farmed fish. Arch. Ani. Nutr., 49: 33-39.

[40] Bayir, A., A.N. Sirkecioğlu, M. Bayır, M. Arslan, M. Güneş, H.I. Haliloğlu, N.M. Aras and H. Arslan, 2011. Effects of dietary lipid source on growth, survival, and fatty acid composition of brown trout juveniles, Salmo trutta. Isr. J. Aquac. Bamidgeh, IIC: 622-630. 